\title{
Vitiligo Fokal pada Anak Yang Diterapi dengan Target Excimer Light $308 \mathrm{~nm}$
}

\author{
Stefani Nurhadi \\ Departemen IImu Kesehatan Kulit dan Kelamin Fakultas Kedokteran Universitas Ciputra \\ Citraland CBD Boulevard, Made, Kecamatan Sambikerep, Surabaya 60219 \\ e-mail: stefani_nurhadi@hotmail.com
}

\begin{abstract}
Abstrak
Vitiligo adalah penyakit kulit didapat yang ditandai oleh makula depigmentasi berbatas tegas disebabkan oleh hilangnya melanosit fungsional secara progresif. Vitiligo biasanya muncul pertama kali saat masa anak- anak atau dewasa muda. Manajemen vitiligo pada anak-anak lebih sulit karena pilihan terapi yang terbatas. Fototerapi target UVB $308 \mathrm{~nm}$ digunakan untuk vitiligo lokal pada anak sehingga dapat lebih terfokus pada lesi dan mengurangi efek samping pada daerah sekitarnya. Seorang anak perempuan berusia 4 tahun, suku Bali, datang ke poliklinik kulit dan kelamin Rumah Sakit Indera Denpasar dengan keluhan bercak putih pada bibir sejak 3 minggu. Berdasarkan anamnesis dan pemeriksaan fisik, diagnosis adalah vitiligo fokal. Pasien diberikan fototerapi target dengan excimer light $308 \mathrm{~nm}$ tiga kali seminggu. Setelah terapi excimer light ke-5, didapatkan respon yang baik ditandai dengan adanya repigmentasi pada tepi lesi tanpa kemerahan maupun lepuh. Terapi bertujuan mencapai hasil terbaik dengan efek samping minimal. Fototerapi target direkomendasikan untuk vitiligo fokal, terutama untuk lesi kecil yang baru serta vitiligo pada anak. Mekanisme kerja fototerapi target tersebut adalah mencetuskan repigmentasi, stabilisasi, imunosupresi dan imunomodulasi. Kesimpulan pada laporan kasus ini adalah bahwa fototerapi target $308 \mathrm{~nm}$ cukup bermanfaat untuk vitiligo fokal pada anak, walaupun memerlukan lebih banyak sesi terapi.
\end{abstract}

Kata Kunci: vitiligo, fototerapi, fototerapi target, excimer light, $308 \mathrm{~nm}$, vitiligo anak

\section{Focal Vitiligo in Children Treated with Target Excimer Light $380 \mathrm{~nm}$}

\begin{abstract}
Vitiligo is a acquired skin disease characterized by a well-defined depigmented macules caused by progressive loss of functional melanocytes. Vitiligo usually appears first during childhood or young adults. Management of vitiligo in children are more difficult because the preference of therapy is limited when compared with adult. Targeted $308 \mathrm{~nm}$ UVB phototherapy is used for local vitiligo in children as it can be focused on the lesion and reduce the side effects. A 4-yearold girl, came to dermato-venereology polyclinic of Indera Hospital Denpasar with complaints of white patch on her lips for 3 weeks. Based on the history and physical examination, she was diagnosed with focal vitiligo. She was treated with targeted $308 \mathrm{~nm}$ excimer light phototherapy three times a week. Five sessions of phototeraphy resulted good response characterized by repigmentation of the lesion without redness and blisters. The therapy aims to achieve the best results with minimal side effects. Phototherapy targets are recommended for local vitiligo and especially for new small lesions as well as pediatric vitiligo. The mechanisms of this phototherapy is to trigger repigmentation, stabilization, immunosuppression and
\end{abstract}


immunomodulation. The conclusion is targeted $308 \mathrm{~nm}$ phototherapy is quite useful for treating vitiligo even though more therapy sessions are needed.

Keyword: vitiligo, phototherapy, targeted phototherapy, excimer light, $308 \mathrm{~nm}$, pediatric vitiligo

\section{PENDAHULUAN}

Nama vitiligo berasal dari bahasa latin "vitium" yang artinya cacat atau belang (Ezzedine and Silverberg, 2016). Vitiligo adalah penyakit kulit didapat yang ditandai oleh makula depigmentasi berbatas tegas yang disebabkan oleh hilangnya melanosit fungsional secara progresif (Ortonne et al, 2009). Vitiligo dapat menyebabkan stigma fisiologis dan sosial diantara individu yang terkena (Birlea et al, 2012). Vitiligo biasanya muncul pertamakali saat masa anak-anak atau dewasa muda, dengan kira-kira setengah kasus diawali sebelum usia 20 tahun (James et al, 2011).

Vitiligo mengenai semua ras dan terjadi pada laki-laki dan perempuan dengan frekuensi yang sama. Vitiligo terjadi pada $1 \%$ populasi dunia (Anstey, 2010). Prevalensi vitiligo konsisten diantara berbagai populasi sekitar $0,38 \%$ pada ras Kaukasia, 0,34\% pada ras Afrika-Karibia, 0,46\% pada ras India, walaupun mungkin lebih jarang pada ras Cina Han yaitu 0,093\% (Birlea et al, 2012). Berdasarkan register pasien poliklinik kulit dan kelamin RSUP Sanglah Denpasar pada tahun 2011 sampai 2014 didapatkan 40 pasien vitiligo yang datang berobat. Sedangkan di poliklinik Rumah Sakit Indera Denpasar pada bulan Mei 2017 didapatkan total 601 kunjungan pasien vitiligo yang menjalankan pengobatan fototerapi.

Pada sebagian besar studi epidemiologi, vitiligo pada anak-anak dikategorikan berdasarkan bentuk klinis menjadi tipe vitiligo segmental (makula depigmentasi mengikuti pola dermatom) dan vitiligo non segmental (Ezzedine and Silverberg, 2016; Birlea et al, 2012; Palit et $a l, 2012$ ). Vitiligo non segmental terdiri dari semua kasus yang tidak digolongkan segmental. Vitiligo fokal, yang termasuk bagian dari vitiligo non segmental, ditandai dengan adanya satu atau sedikit makula pada satu area tetapi tidak terdistribusi dalam pola segmental dan dianggap sebagai bentuk prekursor dari vitiligo generalisata (Birlea et al, 2012).

Berbagai modalitas terapi tersedia untuk terapi vitiligo; namun tidak semua dapat digunakan pada anak (Palit et al, 2012). Beberapa modalitas fototerapi menunjukkan respon repigmentasi yang cukup baik pada pasien vitiligo anak-anak. Fototerapi seluruh tubuh seperti psoralen 
ISSN 1978-2071 (Print); ISSN 2580-5967 (Online) Jurnal Ilmiah Kedokteran Wijaya Kusuma 8(2) : 23-34, September 2019

UV A (PUVA) dan narrow band UV B (NBUVB) sering digunakan pada penyakit yang luas dan cepat menyebar, karena kemampuannya dalam menimbulkan repigmentasi dan stabilisasi penyakit. Sementara fototerapi secara umum memiliki efek samping berupa gatal, rasa terbakar, eritema, rasa menyengat, lepuh, dan fototoksisitas (Ezzedine and Silverberg, 2016). Fototerapi target mungkin tidak memiliki kemampuan stabilisasi untuk lesi yang luas, tetapi fototerapi target dapat membatasi efek samping lokal pada area yang diterapi saja. Fototerapi targeted UVB $308 \mathrm{~nm}$ dipilih karena cukup efektif dan aman digunakan untuk vitiligo lokal pada anak (Palit et al, 2012).

Berikut dilaporkan kasus vitiligo fokal pada anak yang mendapatkan terapi excimer light 308 nm. Kasus ini dilaporkan untuk mengetahui modalitas terapi yang tepat dalam penatalaksanaan vitiligo pada anak dan mengetahui respon terapi excimer light pada vitiligo anak.

\section{KASUS}

Seorang anak perempuan, 4 tahun, suku Bali, warga negara Indonesia, datang ke poliklinik Ilmu Kesehatan Kulit dan kelamin Rumah Sakit Indera pada tanggal 6 Juni 2017 dengan keluhan bercak putih pada wajah sejak 3 minggu.
Heteroanamnesis dari ibu pasien didapatkan timbul bercak putih pada wajah sejak 3 minggu. Awalnya muncul bercak putih pada bibir, kemudian bercak tersebut melebar sampai melewati garis bibir. Keluhan muncul spontan, tanpa adanya garukan atau goresan pada kulit sebelumnya. Tidak ada kelainan kulit yang disadari sebelumnya di tempat area bercak putih. Adanya rambut putih pada area bercak disangkal. Pasien tidak mengeluh nyeri maupun gatal pada lesi tersebut. Tidak ada bercak putih di bagian tubuh lain. Area rambut kepala berwarna putih disangkal.

Pasien sudah berobat ke dokter spesialis Kulit dan kelamin dan disarankan untuk terapi sinar di Rumah Sakit Indera. Riwayat penyakit dahulu, pasien belum pernah mengalami keluhan seperti ini. Tidak ada riwayat penyakit sesak nafas, kencing manis, eksim pada kulit, kemerahan pada wajah jika terkena sinar matahari. Tidak ada riwayat sering berdebar-debar, sering merasa lemas, tangan gemetar. Riwayat alergi terhadap obat tidak ada.

Anggota keluarga yang lain tidak ditemukan keluhan sakit yang sama. Tidak ada riwayat vitiligo dalam keluarga. Riwayat penyakit sesak nafas, kencing manis, eksim pada kulit, kemerahan pada wajah jika terkena sinar matahari pada 
ISSN 1978-2071 (Print); ISSN 2580-5967 (Online) Jurnal IImiah Kedokteran Wijaya Kusuma 8(2) : 23-34, September 2019

anggota keluarga disangkal. Riwayat sosial, pasien adalah anak ke-3. Pasien dilahirkan dengan persalinan normal, cukup bulan dengan berat badan lahir sesuai umur kehamilan. Saat ini pasien belum bersekolah. Tidak ada perubahan tingkah laku seperti murung atau menarik diri dari lingkungan sosial yang terjadi pada pasien setelah mengalami bercak putih di wajahnya. Namun ibu pasien merasa khawatir jika bercak putih tersebut bertambah luas.

Pada pemeriksaan fisik didapatkan kesadaran komposmentis dan keadaan umum baik, denyut nadi 90 kali per menit, frekuensi nafas 20 kali per menit, suhu tubuh $36,8^{\circ} \mathrm{C}$, Visual Analog Scale (VAS) 0 dan berat badan $16 \mathrm{~kg}$. Pada status generalis didapatkan kepala normosefali, pada pemeriksaan kedua mata tidak tampak anemis dan ikterus, tidak didapatkan pembesaran kelenjar getah bening servikal. Pemeriksaan telinga, hidung dan tenggorokan tidak ditemukan kelainan. Pemeriksaan toraks, didapatkan jantung dan paru dalam batas normal, hepar dan lien tidak teraba. Tidak didapatkan pembesaran kelenjar getah bening inguinal. Ekstremitas atas dan bawah didapatkan dalam batas normal.

Status dermatologi lokasi pada bibir atas kanan dan perioral kanan didapatkan makula depigmentasi soliter berbatas tegas, bentuk geografika, ukuran $1 \mathrm{~cm} \times 2$ cm. Tidak didapatkan leukotrikia. Pemeriksaan dengan lampu Wood didapatkan makula depigmentasi yang tampak semakin jelas dibandingkan kulit normal. Tipe kulit termasuk dalam Fitzpatrick IV.



Gambar 1. Makula depigmentasi pada bibir atas kanan dan perioral.

Diagnosis adalah vitiligo fokal dengan diagnosis banding pitiriasis versikolor dan pitiriasis alba. Pemeriksaan kalium hidroksida ( $\mathrm{KOH}$ ) 20\% pada bibir tidak didapatkan adanya blastospora maupun hifa pendek dan pemeriksaan lampu Wood pada area bibir tidak didapatkan fluoresensi warna kuning keemasan, batas area depigmentasi tampak lebih jelas.

Berdasarkan anamnesis, pemeriksaan fisik dan pemeriksaan penunjang diagnosis kerja adalah vitiligo fokal. Tatalaksana adalah fototerapi menggunakan target excimer light $308 \mathrm{~nm}$ 
dengan energi $150 \mathrm{~mJ}$ tiga kali seminggu. Orang tua pasien diberikan komunikasi informasi edukasi mengenai diagnosis penyakit; tujuan, prosedur fototerapi, sesi terapi, efek samping yang dapat terjadi dan kemungkinan hasil yang diperoleh. Pasien disarankan untuk menghindari paparan sinar matahari dan menggunakan tabir surya dengan SPF 30, menggunakan pelindung fisik berupa topi dan payung jika terpapar sinar matahari, hindari trauma berupa gesekan, tekanan atau luka.

Direncanakan pemeriksaan laboratorium untuk skrining penyakit autoimun lainnya seperti darah lengkap, fungsi renal dan liver, gula darah puasa, thyroid stimulating hormone (TSH), free T4 (FT4) dan Antibody Antinuclear (ANA).

PENGAMATAN LANJUTAN (17 Juni 2017)

Pada pengamatan hari ke-11, paska fototerapi sesi ke 5 tampak batas bercak putih sedikit mengecil dan tidak ada muncul bercak putih di tempat yang lain. Tidak didapatkan kemerahan dan lepuh pada lesi di bibir. Orang tua pasien menunda pemeriksaan laboratorium karena tidak ada keluhan pada anak.

Status dermatologi lokasi pada bibir atas kanan dan perioral kanan didapatkan makula depigmentasi soliter berbatas tegas, bentuk geografika, ukuran 0,9 cm x 2 $\mathrm{cm}$. Pemeriksaan dengan lampu Wood didapatkan makula depigmentasi yang tampak jelas dibandingkan kulit normal.

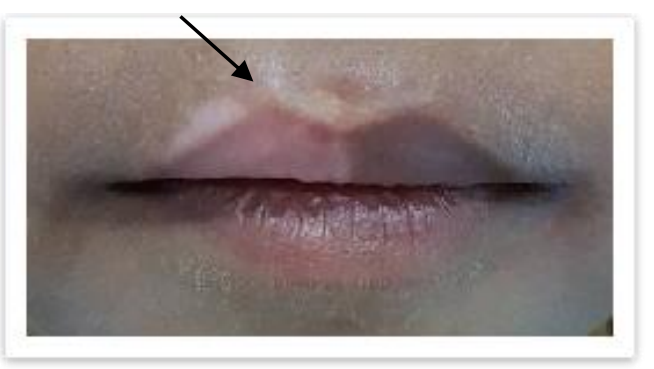

Gambar 2. Makula depigmentasi pada bibir atas kanan dan perioral/ Repigmentasi pada tepi lesi di bibir setelah terapi excimer light sesi ke 5 .

Diagnosis kerja pada pasien adalah vitiligo fokal. Tatalaksana adalah fototerapi menggunakan target excimer light $308 \mathrm{~nm}$ dengan energi $218 \mathrm{~mJ}$ tiga kali seminggu. Orang tua pasien diberikan komunikasi informasi edukasi jadwal untuk sesi terapi selanjutnya, menghindari paparan sinar matahari, menggunakan tabir surya dan perlindungan fisik seperti topi dan payung jika terpapar sinar matahari.

\section{PEMBAHASAN}

Aspek terpenting pada vitiligo adalah gangguan secara kosmetik yang dapat mempengaruhi psikologis pasien dan anggota keluarganya. Vitiligo anak perlu mendapat perhatian khusus karena 50\% onset penyakitnya sebelum usia 20 tahun dan pada $25 \%$ kasus dimulai sebelum usia 10 tahun. Pada umumnya vitiligo anak berbeda dari dewasa dalam hal kecenderungan lebih banyak pada perempuan, tipe segmental lebih sering 
ISSN 1978-2071 (Print); ISSN 2580-5967 (Online) Jurnal IImiah Kedokteran Wijaya Kusuma 8(2) : 23-34, September 2019

dan lebih jarang dihubungkan dengan penyakit autoimun atau endokrin lainnya (Palit et al, 2012).

Pada kasus, pasien adalah seorang anak perempuan berusia 4 tahun yang memiliki keluhan bercak putih pada bibir. Tidak ada perubahan tingkah laku seperti murung atau menarik diri dari lingkungan sosial yang terjadi pada pasien setelah mengalami bercak putih di wajahnya. Namun ibu pasien merasa khawatir jika bercak putih tersebut bertambah luas.

Vitiligo adalah penyakit
multifaktorial poligenik dengan
patogenesis yang kompleks. Banyak
peneliti saat ini menganggap vitiligo
sebagai penyakit dengan etiologi yang
banyak (Habib, 2016). Telah diketahui
bahwa faktor genetik berperan penting
pada perkembangan vitiligo dengan
didapatkannya riwayat keluarga yang
positif pada 30\% pasien, kasus-kasus
vitiligo pada pasien kembar dan bukti
bahwa vitiligo terjadi bersamaan dengan
penyakit yang memiliki dasar genetik yang
jelas seperti diabetes mellitus (Prcic et al,
2011). Pada kasus, pasien tidak memiliki
anggota keluarga yang menderita keluhan
yang sama dengan pasien. Tidak ada
riwayat vitiligo, diabetes mellitus, lupus
dan penyakit tiroid dalam keluarga.

Ada berbagai macam teori mengenai patogenesisnya, teori yang paling diterima adalah terdapatnya interaksi antara faktor genetik dan non genetik dalam mempengaruhi fungsi dan pertahanan hidup melanosit yang akhirnya mengarah ke penghancuran melanosit secara autoimun. Berbagai hipotesis lain yang menduga terjadinya vitiligo adalah hipotesis neural, hipotesis perusakan diri, hipotesis autositotoksik dan stress oksidatif. Pada vitiligo dijumpai adanya antibodi antimelanosit yang bersifat toksik terhadap melanosit dan menghambat pembentukan melanin (Birlea et al, 2012).

Vitiligo ditandai dengan makula putih berbatas tegas, asimtomatik yang dapat lokal maupun generalisata. Beberapa varian klinis vitiligo cenderung terjadi pada masa kanak-kanak (Palit, 2012). Vitiligo diklasifikasikan menjadi subtipe berdasarkan pola dan luas keterlibatan kulit. Vitiligo generalisata yang juga dikenal dengan vitiligo vulgaris, adalah tipe yang paling sering pada pasien pediatrik, terdapat sekitar $33 \%$ sampai $78 \%$ dari pasien vitiligo anak. Pasien tersebut memiliki makula depigmentasi yang simetris pada wajah, leher, badan, aspek ekstensor ekstremitas dan pada tonjolan tulang. Vitiligo fokal tampak pada $14 \%$ sampai $29 \%$ pasien pediatrik dengan vitiligo dan didefinisikan sebagai makula depigmentasi terlokalisir yang tidak sesuai pola dermatom. Vitiligo segmental adalah 
ISSN 1978-2071 (Print); ISSN 2580-5967 (Online) Jurnal Ilmiah Kedokteran Wijaya Kusuma 8(2) : 23-34, September 2019

vitiligo lokal yang sesuai pola dermatom. Tipe ini lebih sering pada anak-anak daripada dewasa yaitu $4 \%$ sampai $19 \%$ pada anak dengan vitiligo. Vitiligo akrofasial mengenai area periorifisial dan distal jari-jari. Jenis ini lebih jarang, tampak hanya pada $1 \%-10 \%$ pasien. Vitiligo universalis adalah depigmentasi lengkap pada seluruh kulit dan sangat jarang (Isenstein et al, 2009; Sheth et al, 2015).

Pada status dermatologis pasien didapatkan lokasi pada bibir atas kanan dan perioral kanan didapatkan makula depigmentasi soliter berbatas tegas, bentuk geografika, ukuran $1 \times 2 \mathrm{~cm}$ dengan pola tidak sesuai dermatom.

Vitiligo paling sering dimulai dari daerah kepala dan leher. Vitiligo fokal diawali dari kepala dan leher pada 69\% pasien (Habib, 2016). Fenomena Koebner tercatat pada vitiligo segmental dan non segmental pada anak. Koebnerisasi dapat lebih sering pada vitiligo anak karena tingginya mobilitas dan suka bermain pada usia tersebut. Adanya Koebnerisasi menunjukkan aktivitas penyakit (Palit et al, 2012). Pada kasus, lesi pasien dimulai dari bibir kanan atas dan menyebar ke daerah perioral.

Pada anak-anak, vitiligo sulit dibedakan dengan kelainan hipopigmentasi lain yang didapat seperti pitiriasis alba, hipopigmentasi paska inflamasi, pitiriasis versikolor dan lepra (Prcic et al, 2011; Isenstein et al, 2009). Pada kasus, diagnosis banding adalah pitiriasis alba dan pitiriasis versikolor.

Pitiriasis alba adalah kelainan pigmen kulit berupa makula hipopigmentasi yang lebih sering terjadi pada anak-anak dibandingkan dengan dewasa. Manifestasi klinis berupa makula hipopigmentasi disertai dengan skuama pada permukaannya. Penyakit ini diawali dengan plak eritema, memiliki batas meninggi dan deskuamasi muncul dalam beberapa minggu. Hipopigmentasi bertahan dalam enam bulan hingga tujuh tahun, terutama terjadi pada pasien dengan dermatitis atopik. Predileksi terutama pada kepala, leher dan ekstremitas atas (Prcic et al, 2011; Isenstein et al, 2009). Pada kasus, lesi kulit tampak depigmentasi yang ketika disinari dengan lampu Wood batas area depigmentasi tampak lebih jelas.

Pitiriasis versikolor disebabkan Pytirosporum ovale, bagian dari flora normal kulit yang pada kondisi tertentu berubah bentuk dari ragi saprofit menjadi fase miselia dan menyebabkan penyakit kulit. Gambaran klinis tampak sebagai makula hipopigmentasi atau kuning kecoklatan berbentuk bulat, oval atau tidak beraturan dengan tepi tidak tegas, berukuran diameter hingga $1 \mathrm{~cm}$ dengan 
ISSN 1978-2071 (Print); ISSN 2580-5967 (Online) Jurnal Ilmiah Kedokteran Wijaya Kusuma 8(2) : 23-34, September 2019

deskuamasi halus pada permukaannya. Diagnosis dibuat berdasarkan klinis dan pada lampu Wood tampak fluoresensi kuning keemasan. Pada pemeriksaan $\mathrm{KOH}$ didapatkan hifa dan spora berbentuk "spaghetti and meatballs" (Isenstein et al, 2009). Pada kasus, pemeriksaan $\mathrm{KOH} 20 \%$ pada bibir tidak didapatkan adanya blastospora maupun hifa pendek dan pemeriksaan lampu Wood tidak didapatkan fluoresensi warna kuning keemasan.

$$
\text { Diagnosis vitiligo ditegakkan }
$$
terutama berdasarkan klinis, yang dapat melibatkan distribusi dan perluasan lesi, dan perjalanan alami penyakit. Oleh karena hubungan antara vitiligo dan penyakit autoimun yang lain, beberapa tes laboratorium berguna, termasuk kadar TSH dan T4, antibodi anti nuklear, dan hitung darah lengkap. Klinisi sebaiknya juga mempertimbangkan pemeriksaan serum anti tiroglobulin dan antibodi anti tiroid peroksidase, terutama ketika pasien memiliki tanda dan gejala mengarah pada penyakit tiroid (Birlea et al, 2012).

Pada kasus, diagnosis ditegakkan berdasarkan riwayat penyakit dan gambaran klinis. Pada pemeriksaan lampu wood lesi tampak lebih jelas menunjukkan lesi vitiligo. Direncanakan pemeriksaan laboratorium untuk menunjang keterlibatan penyakit autoimun seperti
TSH, T4, ANA dan glukosa puasa. Namun orang tua pasien menunda pemeriksaan laboratorium karena tidak ada keluhan pada anak.

Manajemen vitiligo pada anak-anak lebih sulit karena pilihan terapi yang terbatas jika dibandingkan dengan pasien dewasa. Pemilihan terapi sebaiknya berhati-hati dengan tujuan mencapai hasil terbaik dengan efek samping minimal (Palit et al, 2012). Dalam memilih terapi sebaiknya dipertimbangkan usia dan tipe vitiligo, biaya, toleransi dan ketersediaan alat (Prcic et al, 2011; Isenstein et al, 2009). Meskipun menurut panduan konsensus kelompok European Dermatology Forum terdapat terapi topikal untuk terapi lini pertama vitiligo namun belum ada terapi topikal yang diterima oleh Food and Drug Administration (FDA) untuk terapi vitiligo (Isenstein et al, 2009). Pada semua kasus, penting melakukan perlindungan terhadap sinar matahari (Prcic et al, 2011).

Fototerapi target (laser dan non laser) direkomendasikan untuk vitiligo lokalisata (Prcic et al, 2011) dan terutama untuk lesi kecil yang baru saja terjadi serta vitiligo anak. Selain itu juga untuk menghindari efek samping akibat radiasi UVB pada seluruh tubuh dan pada kasuskasus yang kontraindikasi terhadap radiasi seluruh tubuh dengan NB UVB 
ISSN 1978-2071 (Print); ISSN 2580-5967 (Online) Jurnal IImiah Kedokteran Wijaya Kusuma 8(2) : 23-34, September 2019

konvensional (risiko kanker kulit melanoma dan non melanoma serta photoaggravated disease) (Taieb et al, 2012). Baik laser maupun lampu excimer diterima oleh FDA untuk terapi vitiligo (Esmat et al, 2016).

Monochromatic excimer light (MEL) pertamakali diperkenalkan untuk terapi psoriasis pada tahun 1997 dan kasus pertama yang sukses dengan penggunaan laser excimer untuk vitiligo dilaporkan 4 tahun kemudian (Esmat et al, 2016). Mekanisme kerja targeted phototherapy ini terhadap vitiligo masih belum jelas. Seperti NB UVB, excimer light dapat mencetuskan repigmentasi, stabilisasi, imunosupresi dan imunomodulasi. Panjang gelombang tertentu dapat menargetkan keratinosit, melanosit, fibroblas, limfosit dan sel dendritik kulit yang dapat memicu berbagai macam efek seperti apoptosis, deplesi sel $\mathrm{T}$, penurunan antigen dan kemampuan untuk meregulasi mekanisme mediator dan sitokin. Excimer light lebih superior dibandingkan NB UVB dalam apoptosis sel T (Mysore et al, 2016).

Beberapa studi yang telah dipublikasikan menunjukkan efikasi MEL. Pada suatu studi pendahuluan excimer light pada 37 pasien vitiligo, Leone dan kawan-kawan mendapatkan repigmentasi awal pada delapan sesi pertama dan repigmentasi sempurna pada $50 \%$ pasien dalam 6 bulan. Beberapa pasien yang sebelumnya tidak berespon terhadap narrow band UVB didapatkan berespon dengan alat ini (Mysore et al, 2016). Studi tambahan menemukan bahwa terapi dua kali seminggu dengan MEL sebanyak hingga 60 sesi dimulai pada $100 \mathrm{~mJ} / \mathrm{cm}^{2}$ dengan kenaikan $10 \%$ sampai $25 \%$ menghasilkan tingkat repigmentasi lesi yang lebih tinggi pada wajah dibandingkan daerah akral dan aksila (Esmat et al, 2016).

Keistimewaan penggunaan lampu MEL adalah kemampuannya dalam menyinari daerah tubuh yang lebih luas dibandingkan dengan laser excimer. Walaupun demikian kedua alat tersebut sebanding bahkan lebih superior dibandingkan dengan narrow band UVB. Keuntungan dari MEL termasuk terapi yang dibutuhkan tidak terlalu sering dan durasi total terapi yang lebih singkat, sehingga dapat meningkatkan kepatuhan pasien (Esmat et al, 2016).

Pada kasus, pasien diberikan tatalaksana fototerapi menggunakan target excimer light $308 \mathrm{~nm}$ dengan energi awal $150 \mathrm{~mJ}$ tiga kali seminggu dan ditingkatkan $15 \mathrm{~mJ}$ tiap sesi jika tidak didapatkan efek samping eritema atau bula.

Prinsip kunci terapi vitiligo adalah memfasilitasi repopulasi bercak depigmentasi pada interfolikuler epidermis dengan melanosit aktif yang mampu bermigrasi, bertahan untuk repopulasi kulit 
ISSN 1978-2071 (Print); ISSN 2580-5967 (Online) Jurnal IImiah Kedokteran Wijaya Kusuma 8(2) : 23-34, September 2019

depigmentasi dan melakukan biosintesis melanin. Pada praktek klinis, pola repigmentasi yang paling sering dijumpai adalah perifolikuler, walaupun pola yang lain, seperti marginal, difus atau kombinasi dapat juga terjadi. Sumber melanosit utama yang terlibat dalam repopulasi pada kulit vitiligo paling sering adalah prekursor melanosit yang dihasilkan dari selubung akar luar atau area bulge folikel rambut. Simpanan melanosit sekunder bisa terdapat dekat dengan tepi lesi (Birlea et al, 2012).

Repigmentasi yang terjadi dapat dibagi menjadi 5 skala poin yaitu skor 0 apabila tidak terjadi repigmentasi, skor 1 apabila terjadi repigmentasi yang jelek (hingga 25\% area lesi), skor 2 apabila terjadi repigmentasi sedang (antara 26\% dan $50 \%$ ), skor 3 terjadi repigmentasi yang baik (antara51\% dan 75\%) dan skor 4 apabila terjadi repigmentasi yang sangat baik (antara 76\% dan 100\%) (Shi et al, 2013).

Kebanyakan dokter menghentikan penyinaran jika tidak terjadi repigmentasi dalam tiga bulan pertama terapi atau pada kasus yang responnya tidak memuaskan (<25\% repigmentasi) setelah 6 bulan terapi. Fototerapi dilanjutkan selama masih berlangsung repigmentasi atau selama maksimum satu sampai dua tahun (Taieb et al, 2012). Pada kasus, pasien telah mendapatkan fototerapi sebanyak 5 sesi dengan dosis terakhir $218 \mathrm{~mJ}$ dan didapatkan hasil repigmentasi pada tepi lesi (skor 1).

Efek samping yang dapat terjadi pada targeted fototerapi adalah eritema dan bula (Esmat et al, 2016). Pada penelitian yang dilakukan oleh Dong dan kawan-kawan didapatkan efek samping fototerapi target berupa eritema asimtomatik, pruritus dan xerosis, dimana semuanya reda secara spontan dalam beberapa hari. Dapat juga tampak hiperpigmentasi pada perifer lesi yang diterapi, tetapi hal ini hanya berlangsung sementara dan hilang secara bertahap dengan penghentian terapi (Dong et al, 2017). Pada kasus, pasien mengalami efek samping eritema asimtomatis yang hilang dalam 24 jam.

Perjalanan penyakit vitiligo anak kebanyakan stabil atau regresif; hanya sedikit pasien yang mengalami penyakit yang progresif atau rekuren. Repigmentasi spontan lengkap pada vitiligo non segmental jarang terjadi. Namun bila dibandingkan dengan dewasa, tingkat repigmentasi spontan lebih sering terjadi pada anak. Beberapa parameter klinis seperti durasi penyakit yang lama, terjadinya fenomena Koebner, leukotrikia, dan keterlibatan mukosa menunjukkan prognosis yang lebih buruk (Birlea et al, 
ISSN 1978-2071 (Print); ISSN 2580-5967 (Online) Jurnal IImiah Kedokteran Wijaya Kusuma 8(2) : 23-34, September 2019

2012). Selain itu lokasi lesi juga menentukan respon terapi. Lokasi lesi yang berespon baik terdapat pada wajah, respon sedang pada badan dan respon kurang pada tangan dan kaki. Sedangkan area resisten pada wajah yaitu preaurikuler, post aurikuler, bibir dan sudut mulut (Dong et al, 2017).

\section{KESIMPULAN}

Dilaporkan kasus vitiligo fokal pada anak yang mendapatkan terapi excimer light 308 $\mathrm{nm}$ dengan diagnosis vitiligo yang ditegakkan berdasarkan anamnesis dan pemeriksaan fisik. Terapi dengan excimer light $308 \mathrm{~nm}$ yang digunakan tiga kali seminggu, memiliki respon terapi baik yang ditandai dengan adanya repigmentasi (skor 1) pada tepi lesi setelah terapi excimer light ke-5.

\section{DAFTAR PUSTAKA}

Anonim., 2014. Register Pasien Poliklinik RS Sanglah Denpasar periode 20112014.

Anonim, 2017 Register Pasien Ruang Fototerapi Poliklinik Kulit dan Kelamin RS Indera Denpasar periode Mei 2017.

Anstey AV, 210. Disorders of Skin Colour. In: Burns T., Breathnach S., Cox N., Griffiths C. Rook's Textbook of Dermatology 8th. Ed. Oxford:
Blackwell Publishing Ltd. 58:4649.

Birlea SA, Spritz RA, Norris DA, 2012. Vitiligo. In: Goldsmith L.A., Katz S.I., Gilchrest B.A., Paller A.S., Leffel D.J., Wolf K., editors. Fitzpatrick's Dermatology in General Medicine. 8th Ed. New York: McGraw-Hill. 2012:792-803. Dong DK, Pan ZY, Zhang J, Lu XF, Jin C, Tao SQ, Yang LJ, 2017. Efficacy and Safety of Targeted High-Intensity Medium-Band (304-312 nm) Ultraviolet B Light in Pediatric Vitiligo. Pediatric Dermatology, 34(3): 266-270.

Esmat S, Mostafa W, Hegazy RA, Shalaby S, Sheth V, Youssef R, El-Mofty M, 2016. Phototherapy: The vitiligo management pillar. J Clin Dermatol, 34: 594-602.

Ezzedine K, and Silverberg N, 2016. A Practical Approach to the Diagnosis and Treatment of Vitiligo in Children. Pediatrics, 138(1):1-12.

Habib A, 2016. Vitiligo in Children: A Distinc Subset. Journal of the College of Phsicians and Surgeons Pakistan, 26(3):173-176.

Isenstein $\mathrm{AL}$, Morrell DS, Burkhart $\mathrm{CN}$, 2009. Vitiligo: Treatment 
ISSN 1978-2071 (Print); ISSN 2580-5967 (Online) Jurnal IImiah Kedokteran Wijaya Kusuma 8(2) : 23-34, September 2019

Approach in Children. Pediatric Annals, 38(6):339-345.

James WD, Berger TG, Elston DM, 2011. Dermal and subcutaneous tumor. In: Andrews' Diseases of the Skin Clinical Dermatology. United Kingdom: Elsevier, 2011: 860-863.

Mysore V and Shashikumar BM, 2016. Therapeutic guidelines. IADVL. 82(1):1-6.

Ortonne JP, Passeron T, 2009. Vitiligo and Other Disorders of Hypopigmentation. In: Bolognia JL, Jorizzo JL, Schaffer JV. Dermatology $3^{\text {rd }}$ Ed. United States: Elsevier Saunders. 2009: 1023-1029.

Palit A and Inamadar AC, 2017. Childhood Vitiligo. IJDVL. 78(1):30-41.

Patel NS, Paghdal KV, GF, 2012. Advanced Treatment Modalities for Vitiligo. Dermatol Surg, 38: 381-391.

Prcic S, Duran V, Katanic D, 2011. Vitiligo and other hypopigmented disorders in children and adolescent. Acta Medica Academica, 40(2):174-181.

Sheth PK, Sacchidanand S, Asha GS, 2015. Clinico-epidemiological profile of childhood vitiligo. Indian Journal of Paediatric Dermatology, 16(1):23-28.

Shi Q, Li K, Fu J, Wang Y, Ma C, Li Q, Li C, Gao T, 2013. Comparison of the $308 \mathrm{~nm}$ excimer laser with the $308 \mathrm{~nm}$ excimer lamp in the treatment of vitiligo $-a$ randomized bilateral comparison study.

Photodermatol Photoimunol Photomed, 29: 2733.

Taieb A, Alomar A, Bohm M, Dell'Anna ML, De Pase A, Eleftheriadou V, et al, 2013. Guidelines for the management of vitiligo: the European Dermatology Forum consensus. British Association of Dermatologists, 168: 5-19 